\title{
N $87-16891$
}

$\mathrm{CF}_{2}$ and $\mathrm{CFCl}$ Fluorescence from VUV Excitation of $\mathrm{C}_{2} \mathrm{~F}_{3} \mathrm{Cl}$

J. B. Nee a), Xiuyan Wang, Masako Suto and L. C. Lee b) Department of Electrical and Computer Engineering San Diego State Univeraity San Diego, California 92182

\begin{abstract}
The photoexcitation process of $\mathrm{C}_{2} \mathrm{~F}_{3} \mathrm{Cl}$ molecule was invertigated in the $106-230 \mathrm{~nm}$ region using synchrotron radiation as a light source. Photoabsorption and fluorescence cross sections were measured and used to determine the fluorescence quantum yield. Fluorescence yleld starts to appear at $170 \mathrm{~nm}$ and Increases to about $2 \%$ at $155 \mathrm{~nm}$. The fluorescence spectra were dispersed to identify the emitting species. At the excitation wavelength of $155 \mathrm{~nm}$, the emisgion system $18 \mathrm{~B} C \mathrm{Cl}(\widetilde{\mathrm{A}}-\widetilde{\mathrm{X}})$, and at $123.9 \mathrm{~nm}$, both the $\mathrm{CF}_{2}(\tilde{\mathrm{A}}-\tilde{\mathrm{X}})$ and $\mathrm{CFCl}(\tilde{\mathrm{A}}-\tilde{\mathrm{X}})$ eystems are observed. The dissociation processes that produced these excited spectes are discussed.
\end{abstract}
a) Pregent addresg: Dept. of Physica, National Central Univeraity, Taiwan 32
b) also, Department of Chemistry, San Diego State University 


\section{INTRQDUCTION}

In a recent study of reaction kinetics of $\mathrm{HO}_{2}+\mathrm{O}_{3}$ by detecting $\mathrm{HO}_{2}$ with photofragment emiesion in our laboratory, emiasion from excitation of $\mathrm{C}_{2} \mathrm{~F}_{3} \mathrm{Cl}$ at $147 \mathrm{~nm}$ was observed when $1 \mathrm{t}$ was introduced into the system as a scavenger for the of radical [1]. This motivated us to invertigate the photochemistry of $\mathrm{C}_{2} \mathrm{~F}_{3} \mathrm{Cl}$ in vacuum ultraviolet (VUV) region in order to underatand the nature of the UV emission. The VUV absorption spectrum of $\mathrm{C}_{2} \mathrm{~F}_{3} \mathrm{Cl}_{18}$ 1tgelf of interest in understanding the Rydberg states of chlorofluoroethylenes, which show an absorption character similar to that of ethylene. The photoexcitation process of $\mathrm{C}_{2} \mathrm{~F}_{3} \mathrm{Cl}$ is also interesting for the possible role it plays in atmospheric chemistry, because it 18 a member of halocarbons and releases $F$ and $C l$ atoms into the atmosphere by solar radiation.

Photoexcitation of $\mathrm{C}_{2} \mathrm{~F}_{3} \mathrm{Cl}$ may produce excited dihalogen carbene radicals of $\mathrm{CF}_{2}$ and CFCl which are known to heve gtrong transitions in the ultraviolet (UV) region. These radicals can be generated from $\mathrm{F}_{2} \mathrm{C}=\mathrm{CFCl}_{1}$ by chemical reaction with oxygen atoms $[2,3]$, UV photolysis [4-6], and Infrared multiphoton diseociation [7]. The UV emisgion gyatem of $C F_{2}\left(\tilde{A}^{1} B_{1}-\tilde{X}^{1} A_{1}\right)$ has been extensively investigated $[8,9]$; but, the $C F C l\left(\tilde{A}_{A}^{1}{ }^{n}-\widetilde{X}^{1} A^{\prime}\right)$ gystem has been studied only recently [7,10]. Up-to-date information regarding the photoabsorption process of $\mathrm{C}_{2} \mathrm{~F}_{3} \mathrm{Cl}_{1}$ has been summartzed in a recent book by Robin [11]. 


\section{EXPERIMENTAL}

The synchrotron radiation experiment was carried out in the electron storage ring at the University of Wisconsin. Experimental detalls have been described in a previous publication [12]. Synchrotron radiation was dispersed by a 1-m vacuum monochromator before entering a gas cell. UV fluorescence was detected in the direction perpendicular to the light beam by an EMI (95580B) photomultiplier tube (PMT). Light source intensity was measured by another PMT attached to the end of the gas cell. The VUV light source was converted to UV light by sodium salicylate coated outside a LiF window. The optical path length for absorption measurement was $39.1 \mathrm{~cm} . \mathrm{C}_{2} \mathrm{~F}_{3} \mathrm{Cl}$ was supplied by Matheson with a purity better than $99.0 \%$; no further purification was made.

The apparatus for dispersing the fluoreacence spectrum has been degcribed previously [13]. A pulsed discharge lamp associated with a 1-m vacuum monochromator (McPherson 225) was used as the light source. Fluorescence was dispersed by a $0.3-m$ monochromator (McPherson 218) and detected by a PMT (EMI 95580B). Atomic emission lines of CIV at $155 \mathrm{~nm}$ and $N$ at $123.9 \mathrm{~nm}$ were used to excite $\mathrm{C}_{2} \mathrm{~F}_{3} \mathrm{Cl}$. A gated photon counting system was used to process the fluorescence signal.

\section{RESULTS}

The photogbsorption cross section of $\mathrm{C}_{2} \mathrm{~F}_{3} \mathrm{Cl}$ at 106-225 $\mathrm{nm}$ was measured. The absorbance $\ln \left(I_{0} / \mathrm{I}\right)$ was linearly dependent on $\mathrm{C}_{2} \mathrm{~F}_{3} \mathrm{Cl}$ pressure up to $100 \mathrm{mtorr}$ at $105-180 \mathrm{~nm}$. In the $180-230 \mathrm{~nm}$ 
region, $\mathrm{C}_{2} \mathrm{~F}_{3} \mathrm{Cl}_{1}$ gas up to 10 torr was used because of weak absorption. The absorption spectrum obtained at a resolution of $0.2 \mathrm{~nm}$ is shown In Figure 1, curve a. Experimental uncertainty for the absorption crose section 18 eatimated to be within $10 \%$ of the given value. Positions of the $V-N$ transition [14] and the Rydberg serles assigned by Scott and Russel [15] are also indicated in Figure 1.

The total fluorescence cross section measured simultaneously with the absorption cross section 18 shown in Figure 1, curve b. The fluorescence crose eection was calibrated againgt the fluorescence of $\mathrm{OH}(\mathrm{A}-\mathrm{X})$ from VUV photodiseociation of $\mathrm{H}_{2} \mathrm{O}$ for which fluorescence cross aection has been measured [12]. The PMT response was nearly constant in the 185-400 $\mathrm{nm}$ region and decreased at the longer wavelength. Since the fluorescence is essentially in the UV region, the PMT response was not corrected In the fluorescence cross section measurement.

The fluorescence quantum yleld was determined as a ratio of the fluorescence cross section to the absorption crose section. The fluorescence quantum yield in the $106-170 \mathrm{~nm}$ region 1 s ghown In Figure 2. Experimental uncertainty for the fluoreacence cross section 1 s estimated to be within $30 \%$ of the given value.

Fluoregcence spectra from the photodisgociation of $\mathrm{C}_{2} \mathrm{~F}_{3} \mathrm{Cl}$ by atomic lines from a discharge lamp are shown in Figures 3 and 4. Figure $3 a$ shows the dispersed emiseion spectrum excited at 155 $\mathrm{nm}$; Figure $3 \mathrm{~b}$ shows the spectrum when 1 atm of Ar was added for the vibrational relaxation of excited spectes. When the 
vibrational energy was relaxed, the emission shifted to red. This spectrum is Identified as the CFCl $(\tilde{A}-\tilde{X})$ eystem by comparing it with the lager-induced-fluorescence spectrum [7]. The radiative lifetime of $\operatorname{CFCl}(\tilde{A}-\tilde{X})$ is $700 \pm 10 \mathrm{ng}[7]$. Thus, at low gas pressure, the quenching of the emission by parent molecule is negligible.

The emisgion spectrum produced by photoexcitation of $\mathrm{C}_{2} \mathrm{~F}_{3} \mathrm{Cl}_{1}$ at $123.9 \mathrm{~nm}$ is shown in Figure 4. The long wavelength section of this spectrum is similar to Figure $3 a$, but at wavelengths shorter than 350nm, the emiseion 18 malnly due to the $C F_{2}(\tilde{A}-\tilde{X})$ eystem $[8,9]$. These emitting species may not be simultaneously produced by a single photodissociation process such as, $\mathrm{C}_{2} \mathrm{~F}_{3} \mathrm{Cl}_{1} \rightarrow$ $\mathrm{CF}_{2}{ }^{*}+\mathrm{CFCl} 1^{*}$, because thig requireg energy higher than $10 \mathrm{eV}$. The photodissociative excitation of $\mathrm{C}_{2} \mathrm{~F}_{3} \mathrm{Cl}_{1}$ will be discussed later.

\section{DISCUSSION}

\section{A. Photogbsorption Spectrum}

$\mathrm{C}_{2} \mathrm{~F}_{3} \mathrm{Cl}$, like other chlorofluoroethylenes, has an absorption spectrum quite aimilar to that of ethylene [11]. The electronic transition of an electron excited from the $\pi$ orbital of the $C=C$ bond (the ground atate, $N$ ) to the $\pi^{*}$ orbital forma a triplet state, $T$, and a singlet state, $V$. The electron may also be excited to Rydberg states, R. The absorption spectra of ethylene-type molecules have been extensively investigated in the VUV region. The VUV excitation procese is primarily due to the $V$ and $\mathbf{R} \leftarrow N$ transitions; however, the vibronic structures for these molecules have not yet been thoroughly studied [11]. 
Scott and Ruseel [15] have assigned two Rydberg atater for $\mathrm{C}_{2} \mathrm{~F}_{3} \mathrm{Cl}$ among other chlorofluoroethylenes. The Rydberg series converging to the first lonization limit are shown in Figure 1. Using photoelectron spectroscopy, Lake and Thompson [16] determined the vertical ionization potential (transition of maximum probability) of $\mathrm{C}_{2} \mathrm{~F}_{3} \mathrm{Cl}$ to be $10.24 \mathrm{eV}(121.1 \mathrm{~nm}$ ), and adiabatic Ionization potential (transition to $v^{\prime}=0$ of the upper state) to be $9.84 \mathrm{eV}(126 \mathrm{~nm})$. The exclted states of $\mathrm{C}_{2} \mathrm{~F}_{3} \mathrm{Cl}$ have been compared with those of other halogenated-ethylenea by electron-1mpact spectroscopy [17, 18]. The broad continuum extending from about $140 \mathrm{~nm}$ to $225 \mathrm{~nm} 18$ assigned to the $\mathrm{V}-\mathrm{N}$ transition overlapped with Rydberg atates [15]. This continuum is superimposed with the vibrational structure of the $C=C$ stretching mode.

\section{B. Fluorescences of $\mathrm{CF}_{2}$ and CFCl.}

Energy thresholds for the photodissociative excitation process of $\mathrm{C}_{2} \mathrm{~F}_{3} \mathrm{Cl}$ can be determined from the following heats of formation: $\Delta H_{f}=-120.8 \pm 1.1 \mathrm{kcal} / \mathrm{mol}$ for $\mathrm{C}_{2} \mathrm{~F}_{3} \mathrm{Cl}[19],-49 \pm 3$ $\mathrm{kcal} / \mathrm{mol}$ for $\mathrm{CF}_{2}[20]$, and $-2 \pm 7 \mathrm{kcal} / \mathrm{mol}$ for $\mathrm{CFCl}[20]$. The electronic energies for $\mathrm{CF}_{2}\left(\tilde{A}^{1} B_{1}\right)$ and $\mathrm{CFCl}\left(\tilde{A}^{1} A^{n}\right)$ are 4.616 [B] and $3.135 \mathrm{eV}$ [7], respectively. The energieg required for vartous processes are as follows:

$$
\begin{array}{rlr}
\mathrm{C}_{2} \mathrm{~F}_{3} \mathrm{Cl} & \rightarrow \mathrm{CF}_{2}(\tilde{\mathrm{X}})+\mathrm{CFCl}(\tilde{\mathrm{X}}) & \Delta \mathrm{H}=3.02 \mathrm{eV} \\
& \rightarrow \mathrm{CF}_{2}(\widetilde{\mathrm{X}})+\operatorname{CFCl}(\tilde{A}) & 6.16 \mathrm{eV} \\
& \rightarrow \mathrm{CF}_{2}(\tilde{\mathrm{A}})+\operatorname{CFCl}(\tilde{\mathrm{X}}) & 7.64 \mathrm{eV} \\
& \rightarrow \mathrm{CF}_{2}(\tilde{\mathrm{A}})+\operatorname{CFCl}(\tilde{A}) & 10.77 \mathrm{eV}
\end{array}
$$


The other radicale guch as $\mathrm{C}_{2} \mathrm{~F}_{3}$ or $\mathrm{C}_{2} \mathrm{~F}_{2} \mathrm{Cl}_{1}$ may not emit strongly, because the fluorescence spectra shown in Figures 3 and 4 are mainly from $\mathrm{CF}_{2}$ and CFCl.

The spectrum of quantum yleld shows two broad peaks around $123 \mathrm{~nm}$ and $155 \mathrm{~nm}$. Since the excitation of $\mathrm{C}_{2} \mathrm{~F}_{3} \mathrm{Cl}_{1}$ at $155 \mathrm{~nm}$ produces CFCl( $\tilde{A})$ only, the quantum yield in the 135-170 $\mathrm{nm}$ region 1s presumably due to $\operatorname{CFCl}(\tilde{A})$ only, while the second peak at 123 $\mathrm{nm}$ probably indicateg the existence of a state producing $\mathrm{CF}_{2}(\tilde{A})$. As shown in Figure 2, the threshold wavelength for the production of $\operatorname{CFCl}(\tilde{A})$ is at $170 \mathrm{~nm}(7.29 \mathrm{eV})$, and $1 \mathrm{t}$ 18 $11 \mathrm{kely}$ around $135 \mathrm{~nm}$ (9.18 $\mathrm{eV})$ for $\mathrm{CF}_{2}(\tilde{\mathrm{A}})$. These fluorescence thresholds are much higher than the thermochemical thresholds of processes (2) and (3). Thus, the vertical energies of the disgociative gtatea that produce $C_{2}(\tilde{A})$ and $\left.C F C l_{(}\right)$are higher than the dissociation thresholds.

The fluorescence quantum yleld is determined from the transition probability for excitation to a repulsive state (direct dissociation) or the interaction strength between a discrete state and a dissociative state (predissociation). Since the fluorescence quantum ylelde for both the vibrational bands and the absorption continuum in the 140-170 $\mathrm{nm}$ region are about the same, the strength for producing the CFCl(A) by either direct photodissociation process or predissociation process is about the same. The peak for the spectrum of fluorescence yleld can be used to determine the vertical energy of the dissociative otate which 18 about $8.0 \mathrm{eV}$ for $\operatorname{CFCl}(\tilde{A})$ and about $10 \mathrm{eV}$ for $\mathrm{CF}_{2}(\widetilde{A})$. 
For the $10 \mathrm{eV}$ band, the peak wavelength of quantum yield may be affected by the onset of lonization process. In general, the fluorescence quantum yleld decreases at wavelengths shorter than Ionization limit.

The shift of the CFCl emission spectrum to red when Ar is added as shown in Figures $3 a$ and $3 b$ indicates that CFCl( $\tilde{A})$ is vibrationally excited. Based on the threshold energy of process (2), an excess energy of 1.84 eV 18 avallable. This excess energy is enough to excite the molecule into high vibrational quantum numbers which can be calculated from the opectroacopic data $(6,9)$. However, the vibrational spectrum shown in Figure 3 is very complicated, it is difficult to assign vibrational levels.

\section{CONCLUSION}

The photoabsorption and fluorescence cross sections of $\mathrm{C}_{2} \mathrm{~F}_{3} \mathrm{Cl}$ have been measured in the $106-230 \mathrm{~nm}$ region. Fluorescence spectra have been dispersed and identified to be the $\mathrm{CF}_{2} \tilde{A}^{1} \mathrm{~B}_{1}$ $\left.\widetilde{\mathrm{X}}^{1} \mathrm{~A}_{1}\right)$ and $\operatorname{CFC}\left(\tilde{A}^{1} A^{n}-\widetilde{\mathrm{X}}^{1} A^{\prime}\right)$ gyatems. The spectrum of fluorescence quantum yield shows two dissociative states. The threshold wavelengthe for producing $\operatorname{CFCl}(\widetilde{A})$ and $\mathrm{CF}_{2}(\widetilde{A})$ were determined to be 170 and $135 \mathrm{~nm}$, respectively.

\section{ACKNOWLEDGEMENT}

We wish to thank M. J. Mitchell, W. C. Wang, and C. Ye in our laboratory for useful discuseion and euggestions. The aynchrotron radiation facility at the University of Wisconsin is supported by the NSF under Grant No. DMR-44-21888. This material 
is based on the work supported by the NSF under Grant No. ATM8412618 and the NASA under Grant No. NAGW-661. 


\section{REFERENCES}

1. E. R. Manzanarea, M. Suto, L. C. Lee and D. Coffey Jr., J. Chem. Phys. In press.

2. H. Meunier, J. R. Durdy, and B. A. Thrush, J. C. S. Faraday II, 76 (1980) 1304.

3. F. J. Comer and D. A. Rameey, J. Mol. Spectrosc. 113 (1985) 495.

4. J. J. Tiee, F. B. Wampler, and W. W. Rice Jr., Chem. Phya. Lett. 73 (1980) 519.

5. 5. Koda, Chem. Lett. 1 (1980) 57.

6. T. Hikida, T. Tozawa, and Y. Mori, Chem. Phys. Lett. 70 (1980) 579.

7. S. E. Bialkowski, D. S. King, and J. C. Stephenson, J. Chem. Phys. 71 (1979) 4010.

8. C. W. Mathews, Can. J. Phye. 45 (1967) 2355.

9. D. S. King, P. K. Schenck, and J. C. Stephenson, J. Mol. Spectrosc. 78 (1979) 1.

10. V. E. Bondybey and J. H. English, J. Mol. Spectrosc. 68 (1977) 89.

11. M. B. Robin, Higher Excited Stateg of Polyatomic Moleculeg, Academic Press, Orlando, 1985.

12. L. C. Lee, J. Chem. Phys. 72 (1980) 4334.

13. M. Suto, X. Wang and L. C. Lee, J. Chem. Phyz. in press.

14. A. J. Merer and R. S. Mulliken, Chem. Rev. 69 (1969) 639.

15. J. D. Scott and B. R. Rugsel, J. Amer. Chem. Soc. 94 (1972) 2634. 
16. R. F. Lake and H. Thompeon, Proc. Roy. Soc. Lond. A315 (1970) 323.

17. M. J. Cogglola, W. M. Flicker, O. A. Mohser, and A. Kuppermann, J. Chem. Phyв. 65 (1976) 2655.

18. G. J. Verhaart and H. H. Brongerama, Chem. Phys. 52 (1980) 431.

19. P. A. Evastov and V. P. Kolegov, J. Chem. Thermodynamica 14 (1982) 103.

20. 5. G. Lias, Z. Karpas, J. F. Lifuman, J. Amer. Chem Soc. 107 (1985) 6089. 


\section{FIGURE CAPTIONS}

Fig. 1. Photoabsorption and fluorescence crose sections of $\mathrm{C}_{2} \mathrm{~F}_{3} \mathrm{Cl}_{1}$ in the $106-230 \mathrm{~nm}$ region in units of $\mathrm{Mb}\left(10^{-18}\right.$ $\mathrm{cm}^{2}$ ). The wavelength positions of the $\mathrm{V} \leftarrow \mathbf{N}$ transition and the Rydberg series assigned by scott and Russel are indicated.

Fig. 2. Fluorescence quantum yield in the 106-175 $\mathrm{nm}$ region. The dashed line represents an average value.

Fig. 3. Fluoregcence epectra produced by photoexcitation of $\mathrm{C}_{2} \mathrm{~F}_{3} \mathrm{Cl}_{1}$ at $155 \mathrm{~nm}$. (a) Pure $\mathrm{C}_{2} \mathrm{~F}_{3} \mathrm{Cl}_{1}$ of 80 mtorr and (b) 1 atmosphere Ar was added to (a). The monochromator resolution was $4 \mathrm{~nm}$. The fluorescence spectrum is Identified to be the $\operatorname{CFCl}(\tilde{A}-\widetilde{X})$ system.

Fig. 4. Fluorescence spectrum produced by photoexcitation of 80 mtorr $\mathrm{C}_{2} \mathrm{~F}_{3} \mathrm{Cl}_{1}$ at $123.9 \mathrm{~nm}$. The monochromator resolution was $4 \mathrm{~nm}$. 


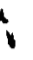

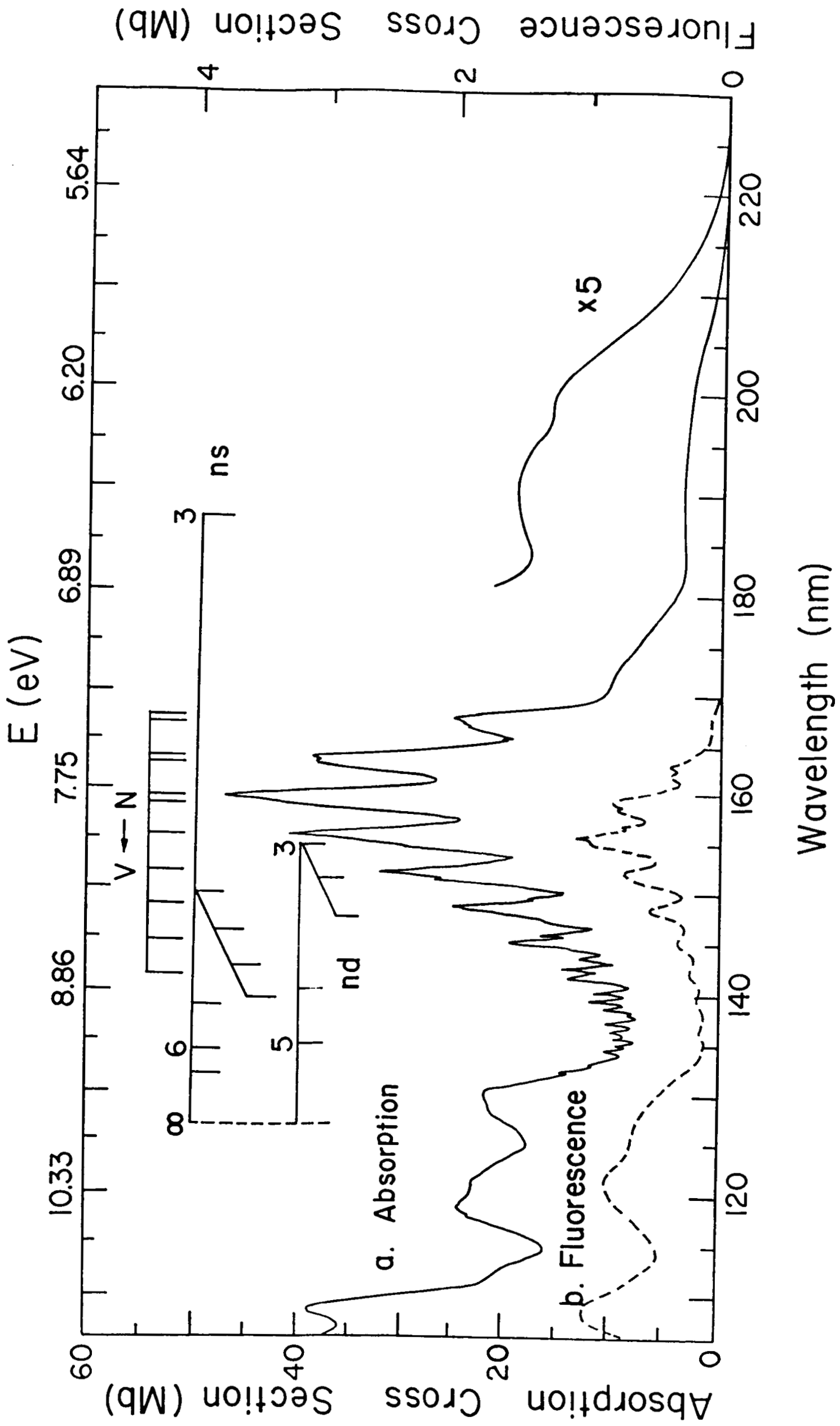

Fig. 1 
23

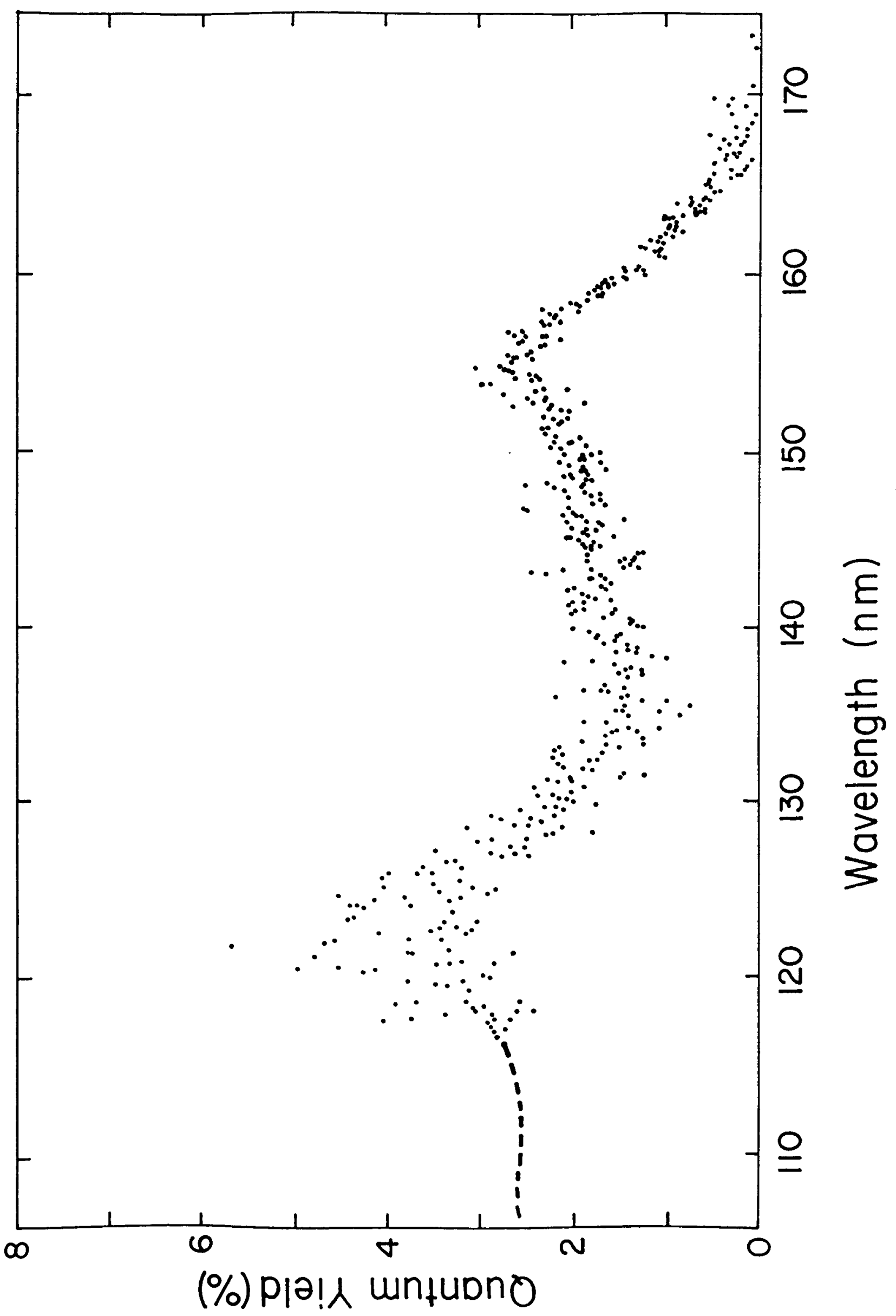




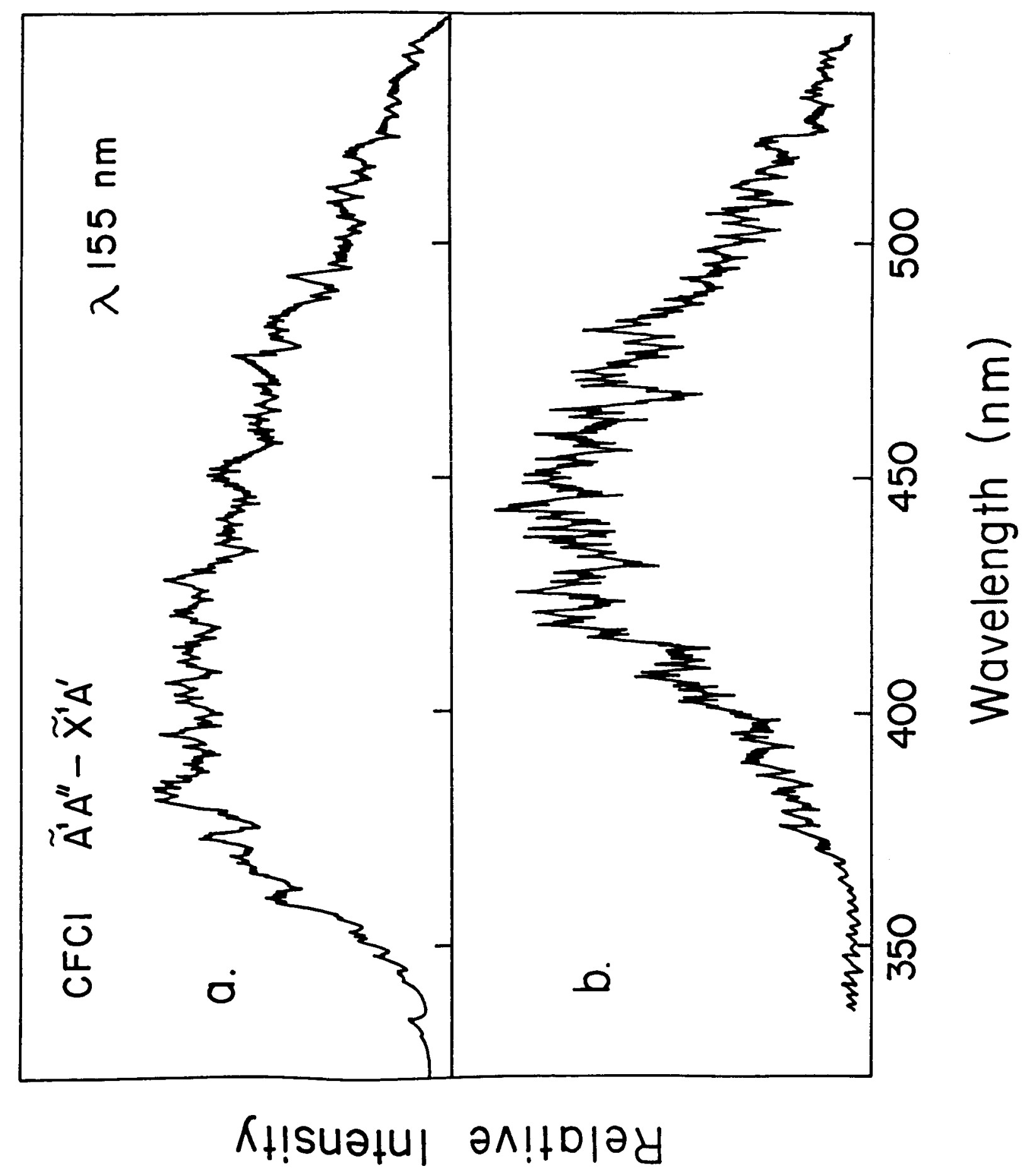

$F i g, 3$ 


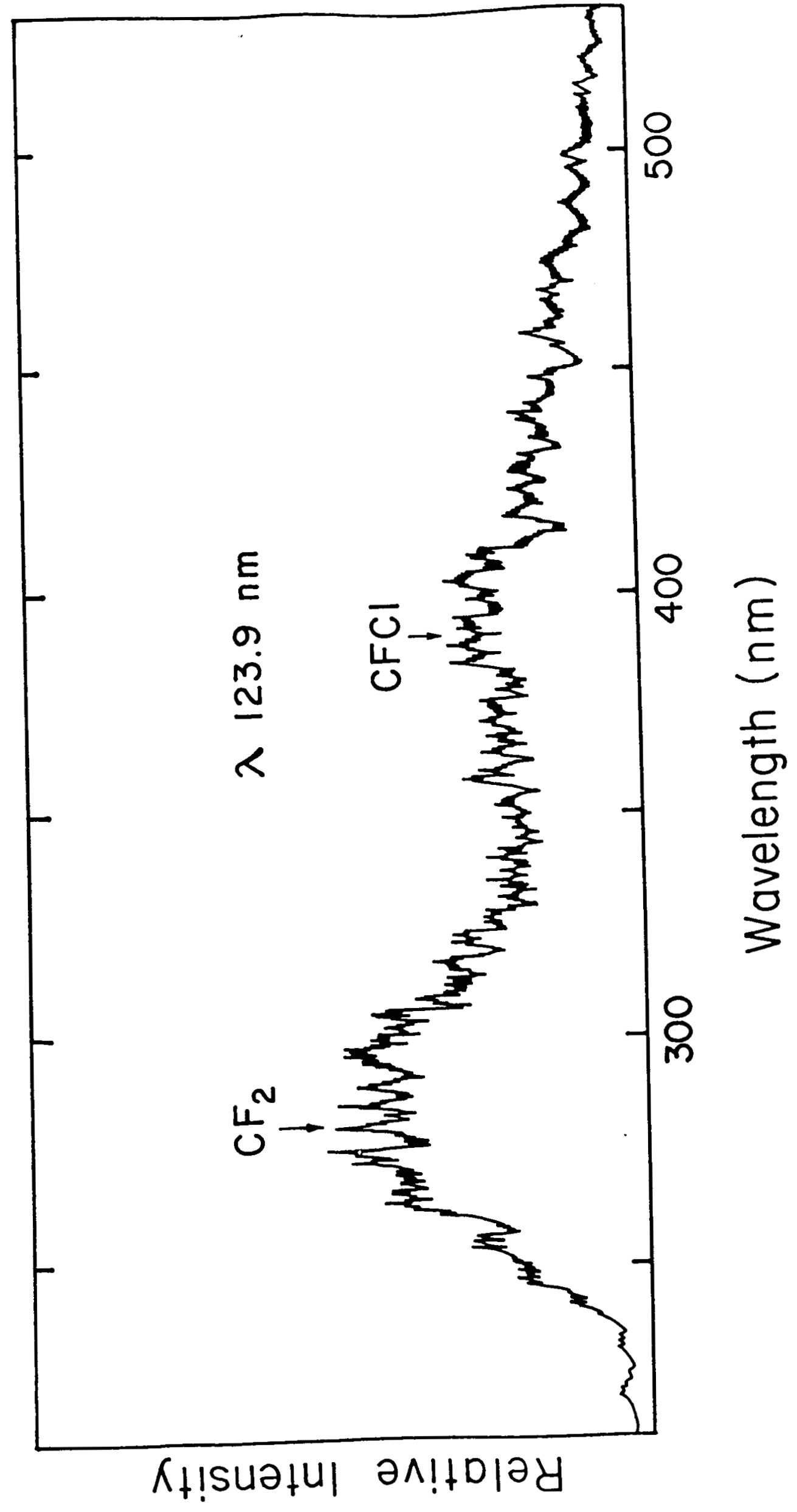

